\title{
Glutamate dehydrogenase and glutamine synthetase are regulated in response to nitrogen availability in Myocbacterium smegmatis
}

\author{
Catriona J Harper*1, Don Hayward ${ }^{1}$, Martin Kidd 2 , Ian Wiid ${ }^{1}$ and Paul van Helden ${ }^{1}$
}

\begin{abstract}
Background: The assimilation of nitrogen is an essential process in all prokaryotes, yet a relatively limited amount of information is available on nitrogen metabolism in the mycobacteria. The physiological role and pathogenic properties of glutamine synthetase (GS) have been extensively investigated in Mycobacterium tuberculosis. However, little is known about this enzyme in other mycobacterial species, or the role of an additional nitrogen assimilatory pathway via glutamate dehydrogenase (GDH), in the mycobacteria as a whole. We investigated specific enzyme activity and transcription of GS and as well as both possible isoforms of $\mathrm{GDH}_{\text {(NAD+- }}$ and NADP+-specific GDH) under varying conditions of nitrogen availability in Mycobacterium smegmatis as a model for the mycobacteria.

Results: It was found that the specific activity of the aminating NADP+-GDH reaction and the deaminating NAD+-GDH reaction did not change appreciably in response to nitrogen availability. However, GS activity as well as the deaminating $\mathrm{NADP}^{+}-\mathrm{GDH}$ and aminating $\mathrm{NAD}^{+}-\mathrm{GDH}$ reactions were indeed significantly altered in response to exogenous nitrogen concentrations. Transcription of genes encoding for GS and the GDH isoforms were also found to be regulated under our experimental conditions.

Conclusions: The physiological role and regulation of GS in M. smegmatis was similar to that which has been described for other mycobacteria, however, in our study the regulation of both NADP+- and NAD+-GDH specific activity in $M$. smegmatis appeared to be different to that of other Actinomycetales. It was found that NAD+-GDH played an important role in nitrogen assimilation rather than glutamate catabolism as was previously thought, and is it's activity appeared to be regulated in response to nitrogen availability. Transcription of the genes encoding for NAD+-GDH enzymes seem to be regulated in M. smegmatis under the conditions tested and may contribute to the changes in enzyme activity observed, however, our results indicate that an additional regulatory mechanism may be involved. $\mathrm{NADP}^{+}-\mathrm{GDH}$ seemed to be involved in nitrogen assimilation due to a constitutive aminating activity. The deaminating reaction, however was observed to change in response to varying ammonium concentrations which suggests that $\mathrm{NADP}^{+}-\mathrm{GDH}$ is also regulated in response to nitrogen availability. The regulation of NADP+-GDH activity was not reflected at the level of gene transcription thereby implicating post-transcriptional modification as a regulatory mechanism in response to nitrogen availability.
\end{abstract}

\section{Background}

Nitrogen is incorporated into glutamate and glutamine which form the major biosynthetic donors for all other nitrogen containing components in a cell. Glutamine is a source of nitrogen for the synthesis of purines, pyrimi-

* Correspondence: carrie@sun.ac.za

${ }^{1}$ DST/NRF Centre of Excellence for Biomedical TB Research, Department of Molecular Biology and Human Genetics, Faculty of Health Sciences, University of Stellenbosch, P.O.Box 19063, Tygerberg, South Africa

Full list of author information is available at the end of the article dines, a number of amino acids, glucosamine and $\rho$-benzoate, whereas glutamate provides nitrogen for most transaminases [1] and is responsible for $85 \%$ of nitrogenous compounds in a cell [2]. In most prokaryotes, there are two major routes for ammonium assimilation. The glutamine synthetase (GS) and glutamate synthase (GOGAT) cyclic mechanism is largely active when exogenous nitrogen concentrations are limiting, due to the high affinity of GS for ammonium. This pathway utilizes 
approximately $15 \%$ of the cell's ATP requirement [1] for the production of glutamine and its activity is, therefore, strictly regulated at both transcriptional and post-translational levels in order to prevent energy wastage (see Figure $1 \mathrm{~A})$.

Under conditions of nitrogen excess, glutamine synthetase activity is reduced via adenylylation by the adenylyltransferase $G \operatorname{lnE}[3,4]$ and under these conditions, the low ammonium affinity glutamate dehydrogenase (GDH) pathway plays a major assimilatory role with a comparatively low associated energy cost [5]. GDH enzymes catalyse the reversible amination of $\alpha$-ketoglutarate to form glutamate (see Figure 1B) with concomitant reduction of $\mathrm{NAD}(\mathrm{P}) \mathrm{H}$. They also serve as metabolic branch enzymes as the GDH enzymes are involved in anapleurotic processes which regulate the flux of intermediates such as $\alpha$ ketoglutarate between the Krebs cycle and nitrogen metabolism [6]. The GDH enzymes identified in prokaryotes usually function with either $\mathrm{NADP}^{+}$(EC 1.4.1.4) or $\mathrm{NAD}^{+}$(EC 1.4.1.2) as co-factors whilst in higher eukaryotes the enzymes have dual co-factor specificity (EC 1.4.1.3). $\mathrm{NADP}^{+}$-specific enzymes are normally involved in the assimilation of nitrogen via amination of $\alpha$-ketoglutarate [7] and may be transcriptionally regulated by a variety of growth conditions, including carbon and nitro-

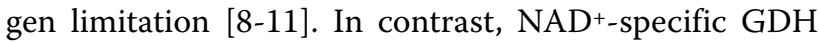
enzymes are thought to be largely involved in glutamate catabolism (deamination) [12-14] and do not appear to be regulated in response to ammonium limitation $[15,16]$. GDH enzymes described to date are oligomeric structures and can be grouped into three subgroups according to subunit composition. Many NADP+- and NAD+-GDH enzymes from a number of organisms are hexameric structures made up of subunits that are approximately 50 $\mathrm{kDa}$ in size [6]. The second GDH class comprise NAD ${ }^{+}$ specific GDH enzymes with tetrameric structures whose subunits have a molecular mass of approximately $115 \mathrm{kDa}$ [17]. Recently, a third class of oligomeric $\mathrm{NAD}^{+}$-specific GDH enzymes was defined whose subunits are approximately $180 \mathrm{kDa}$ in size [18-20].

Information regarding nitrogen metabolism and its regulation in the mycobacteria is relatively limited. Glutamine synthetase (encoded by $g \ln A 1$ ) has traditionally formed an isolated focal point of study with regard to nitrogen metabolism in the mycobacteria as it has been associated with Mycobacterium tuberculosis virulence and pathogenicity $[21,22]$. It has previously been demonstrated that GS from pathogenic mycobacterial species such as M. tuberculosis and M. bovis is exported, [23] yet the reasons for this phenomenon and the mechanism of export remain obscure [24]. It has been speculated that extracellular GS may play a role in the production of polyL-glutamine-glutamate [25], a polymer found only in pathogenic mycobacterial cell walls, and/or that extracellular GS activity may modulate phagosome $\mathrm{pH}$ and thereby prevent phagasome-lysosome fusion [23,24]. Comparatively little is known about GS in other mycobacterial species, such as Mycobacterium smegmatis, or GDH in the mycobacteria as a whole. The M. smegmatis genome encodes for a variety of putative glutamine synthetase enzymes which encode for each of the four possible classes of GS proteins [26], many of which serve

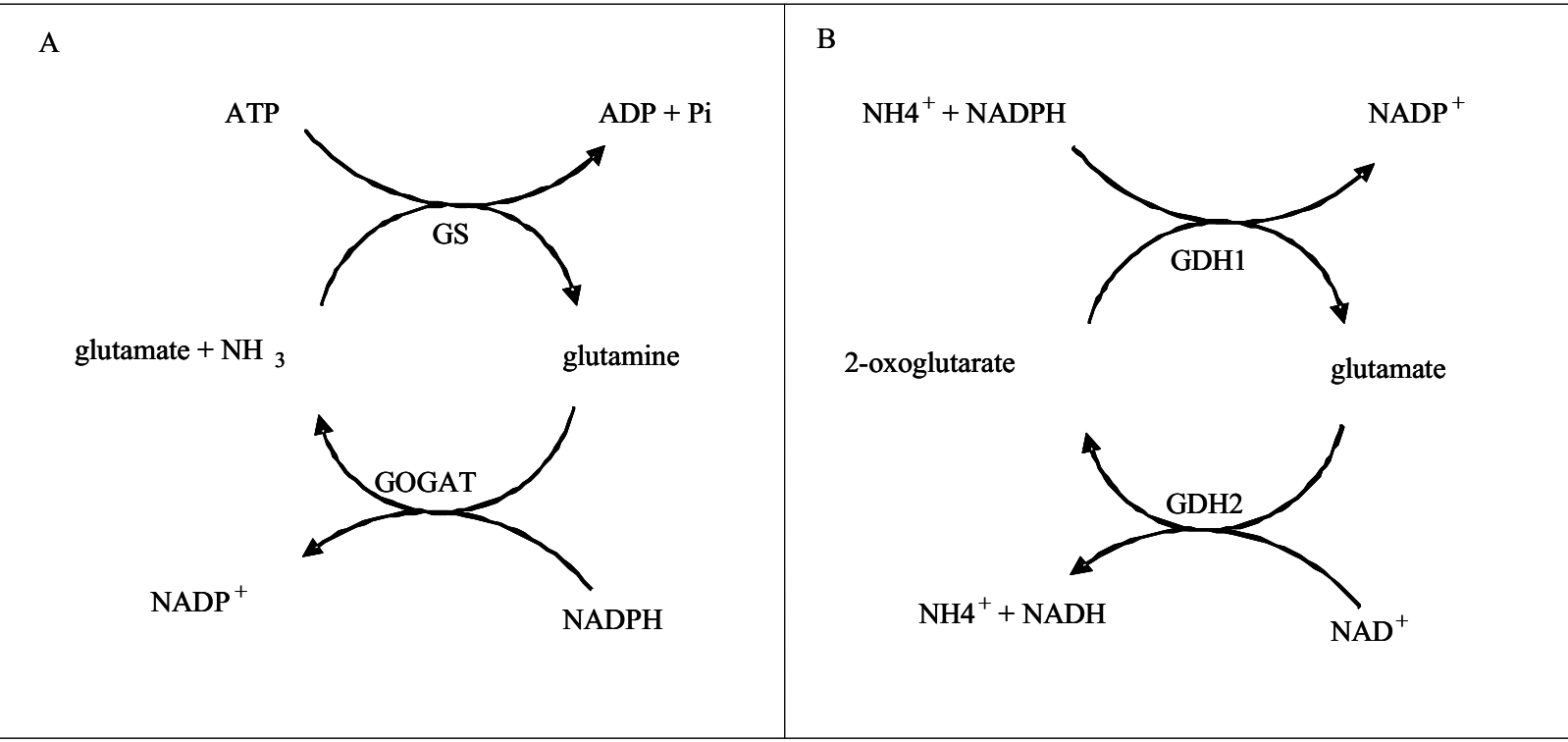

Figure 1 Assimilation of nitrogen by (A) GS and GOGAT; (B) NADP+ - dependant-glutamate dehydrogenase (GDH1) and NAD+-dependant glutamate dehydrogenase (GDH2) 
unknown functions. Of these homologs, msmeg_4290 has the greatest amino acid identity to gln $A 1$ in $M$. tuberculosis, which encodes for a GS type 1 ammonium assimilatory enzyme [27]. The M. smegmatis GS seems different to $M$. tuberculosis GS in that it does not appear to be expressed to such a high level, nor does it appear to be exported to the extracellular milieu [23,24].

The M. smegmatis genome also encodes for an $\mathrm{NADP}^{+}$ GDH (msmeg_5442) which was isolated by Sarada et al. [28]; an L_180 class $\mathrm{NAD}^{+-} \mathrm{GDH}$ (msmeg_4699) [29] as well a second putative $\mathrm{NAD}^{+-G D H}$ enzyme (msmeg_6272). In contrast, the M. tuberculosis genome only encodes for a single putative $\mathrm{NAD}^{+}$-specific $\mathrm{GDH}$ $(R v 2476 c)$ whose activity was detected in culture filtrates by Ahmad et al [30]. The enzyme shares a $71 \%$ amino acid identity with MSMEG_4699 and may also belong to the L_180 class of $\mathrm{NAD}^{+}-\mathrm{GDH}[18,29]$.

$\mathrm{NAD}^{+}$-specific glutamate dehydrogenases belonging to the L_180 class have been characterised in four organisms to date, namely Streptomyces clavuligerus [18], Pseudomonas aeruginosa[20], Psychrobacter sp. TAD1 [31] and Janthinobacterium lividum [19], however little functional work has been done on these enzymes. It has very recently been found that the $\mathrm{NAD}^{+-G D H}$ (MSMEG_4699) isolated from M. smegmatis may belong to this class and that it's activity is affected by the binding of a small protein, GarA. This small protein is highly conserved amongst the actinomycetes and was given the name glycogen accumulation regulator (GarA) due to its observed effects on glycogen metabolism in Mycobacterium smegmatis [32], however it's precise function remained unclear at the time. GarA has a fork-head associated (FHA) domain which is able to mediate proteinprotein interactions as well as a highly conserved N-terminal phosphorylation motif in which a single threonine residue may be phosphorylated by either serine/threonine kinase $B(P k n B)$ [33] or serine/threonine kinase $G$ (PknG) [29] thereby presumably playing a role in phosphorylation-dependant regulation mechanisms [34]. It has been shown that Odh1 (the GarA ortholog in C. glutamicum; 75\% amino acid identity) is able to bind 2-oxoglutarate dehydrogenase, a key TCA cycle enzyme, and cause a reduction in it's activity. This inhibition of enzyme activity was removed by phosphorylation of Odh1 by PknG [35]. A similar phenomenon has been observed in $M$. smegmatis with regards to the modulation of $\mathrm{NAD}^{+}-\mathrm{GDH}$ by GarA. Native or unphosphorylated GarA has been shown to be able to interact with NAD+GDH causing a reduction in $\mathrm{NAD}^{+-} \mathrm{GDH}$ activity by altering the affinity of the enzyme for its substrate [29]. This binding, however, is prevented by the phosphorylation of GarA [29] by PknG. The conditions under which $\mathrm{PknG}$ is stimulated to phosphorylate or dephosphorylate
GarA has not yet been investigated and it is not clear how the relationship between GarA, $\mathrm{NAD}^{+-} \mathrm{GDH}$ and PknG may impact nitrogen metabolism in the mycobacteria.

The physiological roles as well as the regulation of the major effectors of nitrogen metabolism (GS and GDH) in $M$. smegmatis remains unclear. As the adaptive mechanisms of the mycobacteria to limited nitrogen availability remain vague, an investigation into the changes in activity and transcription of both glutamine synthetase and the glutamate dehydrogenase enzymes under various conditions of ammonium availability in $M$. smegmatis, as a model for the mycobacteria, has been undertaken.

\section{Results and Discussion}

\section{GDH specific activity in response to ammonium limitation} and excess

To investigate the effect of nitrogen availability on GDH activity, M. smegmatis was cultured in minimal medium containing a limited amount of ammonium (3 $\mathrm{mM}$ $\left.\left(\mathrm{NH}_{4}\right)_{2} \mathrm{SO}_{4}\right)$. The specific activity of both the aminating and deaminating reactions catalysed by $\mathrm{NAD}^{+}{ }_{-}$and $\mathrm{NADP}^{+}-\mathrm{GDH}$ (see Reaction 2) was determined from $M$. smegmatis whole cell lysates sampled at 0; 0.5; 2 and 4 hour intervals. The effect of an ammonium pulse $(60 \mathrm{mM}$ $\left.\left(\mathrm{NH}_{4}\right)_{2} \mathrm{SO}_{4}\right)$ on $\mathrm{GDH}$ activity was determined after 0.5 and 1 hours exposure to those conditions.

The NADP+-GDH forward or aminating reaction activity in $M$. smegmatis did not change appreciably in response to ammonium availability as can be seen by the absence of any significant change in activity between $0 \mathrm{hr}$ and 0.5 or $1 \mathrm{hr}$ nitrogen starvation (Figure $2 \mathrm{~A}, \mathrm{O})$. This was also true for M. smegmatis exposed to an ammonium pulse (Figure 2A, $\mathbf{0}$ ). It would appear as though the $\mathrm{NADP}^{+-} \mathrm{GDH}$ aminating reaction activity of $M$. smegmatis exposed to nitrogen limitation remained greater than that of $M$. smegmatis exposed to ammonium excess conditions (Figure 2A). This, however, could be misleading as, at certain time points, the bacteria were exposed to similar conditions of nitrogen availability in each experiment. For example, $M$. smegmatis incubated for $1 \mathrm{hr}$ in media containing $60 \mathrm{mM} \mathrm{NH}_{4}{ }^{+}$at time point $0 \mathrm{hr}$ before being starved of nitrogen (Figure 2A, $\mathrm{O}$ ) was the same as after $1 \mathrm{hr}$ exposure to ammonium excess conditions (Figure $2 \mathrm{~A}, \mathbf{\square})$. The activity of the $\mathrm{NADP}^{+}-\mathrm{GDH}$ reaction is expected to be relatively similar under homologous conditions, thus the disparity observed may be due to slight experimental differences in the amount of starting material, assay conditions or absorbance readings measured during the activity assays. Our results also show that NADP+-GDH aminating reaction activity did not change significantly in response to prolonged exposure to nitrogen limitation (Table 1). This lack of change in M. smegmatis $\mathrm{NADP}^{+-} \mathrm{GDH}$ reaction activity is in contrast to a 


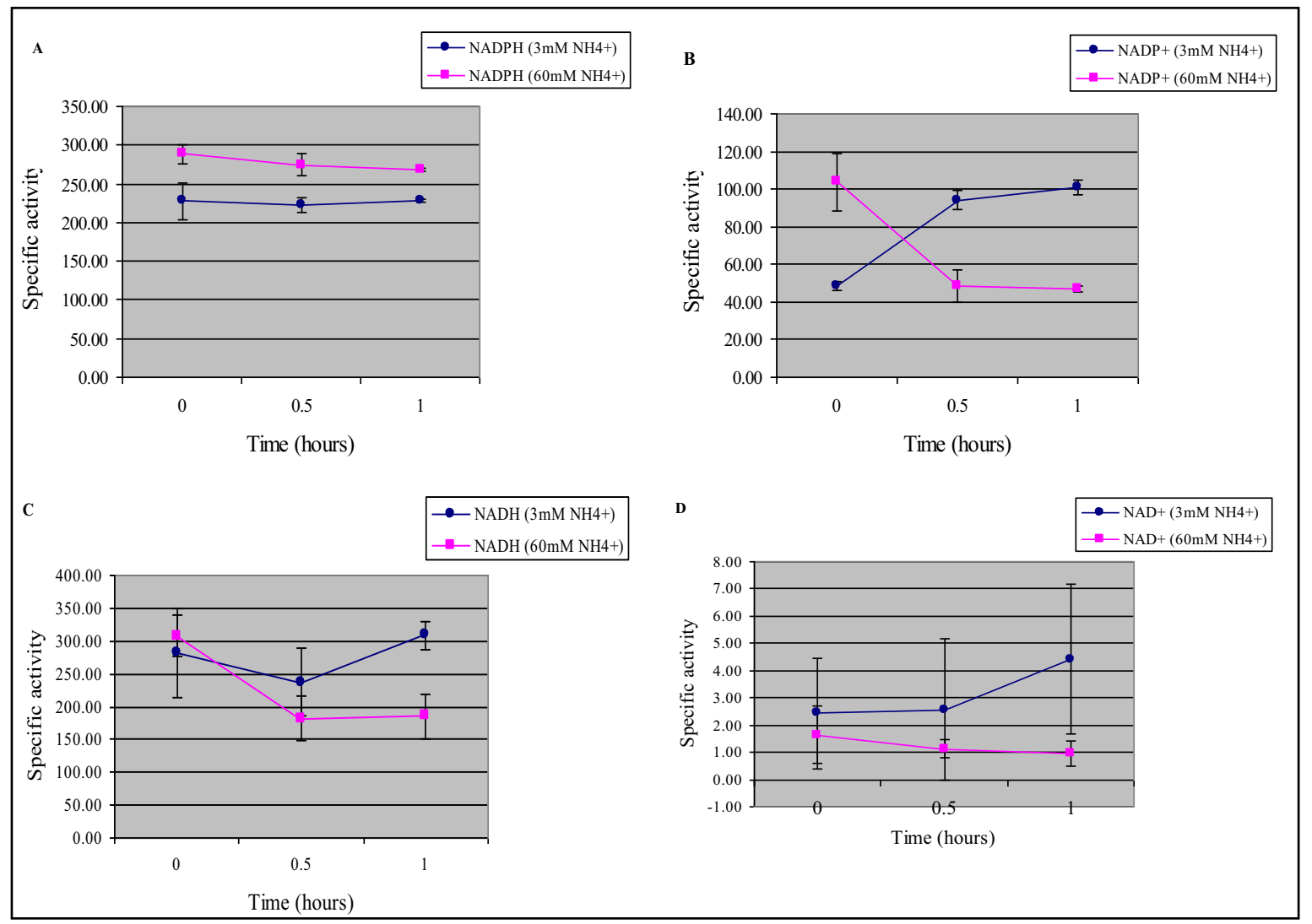

Figure 2 Specific activities of the (A) NADP+-specific forward reaction in which NADPH was added as co-factor, (B) NADP+-specific reverse reaction in which NADP+ was utilised as co-factor, (C) NAD+-specific forward reaction with NADH as co-factor and (D) NAD+-specific reverse reaction in which $\mathrm{NAD}^{+}$was utilised as co-factor. Each enzyme reaction was assayed under conditions of nitrogen limitation $\left(3 \mathrm{mM}\left(\mathrm{NH}_{4}\right)_{2} \mathrm{SO}_{4}\right)$ and in response to an ammonium pulse $\left(60 \mathrm{mM}\left(\mathrm{NH}_{4}\right)_{2} \mathrm{SO}_{4}\right)$. One unit of enzyme activity was defined as the oxidation/reduction of $1 \mathrm{nmole}$ co-factor per minute per milligram ofprotein. The mean specific activity with standard deviations is included.

recent study in which $\mathrm{NADP}^{+}-\mathrm{GDH}$ animating activity was found to increase significantly in response to nitrogen starvation in a related Actinomycete, Corynebacterium glutamicum [36]. In other bacterial species, NADP+-GDH forward reaction activity has been shown to be down-regulated in response to nitrogen excess $[37,38]$ or not regulated at all [39].

Upon analysis of the NADP+-GDH reverse or deaminating reaction activity, our results showed that there was a significant change in activity in response to nitrogen availability in M. smegmatis (Figure 1B) thereby suggesting NADP+-GDH is indeed regulated in response to varying nitrogen concentration conditions. When exposed to ammonium starvation conditions, there was a 2 fold increase (Figure 2B, - and Table $1, \mathrm{p}=0.01$ ) in NADP+GDH deaminating reaction activity (i.e. glutamate catabolism), which remained constant throughout an extended period of nitrogen starvation (Table 1). The converse effect was observed under conditions of nitrogen excess, namely a rapid, approximately 2 fold decrease in reaction activity (Figure $2 \mathrm{~B}, \mathbf{\square}$ ). Since $\mathrm{NADP}^{+}-\mathrm{GDH}$ performs a reversible reaction, it is interesting to note that a change only in the deaminating reaction activity in response to nitrogen availability was detected. The functional significance of the observed change in glutamate deamination is unclear. It may be that the modulation of glutamate catabolism serves to maintain the intracellular glutamate/ 2-oxoglutarate ratios which is known to co-ordinate a number of cellular activities such as growth rate modulation [40]; maintenance of intracellular potassium pools [41] and protection from high osmotic environments [42].

There are two possible $\mathrm{NAD}^{+}-\mathrm{GDH}$ enzymes encoded by the $M$. smegmatis genome. The highly $\mathrm{NAD}^{+}$specific GDH encoded by msmeg 4699 was isolated and characterised by O'Hare et al. [29] which showed great similarity to the novel class of large GDH enzymes known as the L_180 class [18]. The second putative $\mathrm{NAD}^{+-G D H}$ is 
Table 1: Specific activities of the both the aminating and deaminating reactions for NADP- and NAD-glutamate dehydrogenase enzymes in response to nitrogen starvation conditions $\left(3 \mathrm{mM}\left(\mathrm{NH}_{4}\right)_{2} \mathrm{SO}_{4}\right)$.

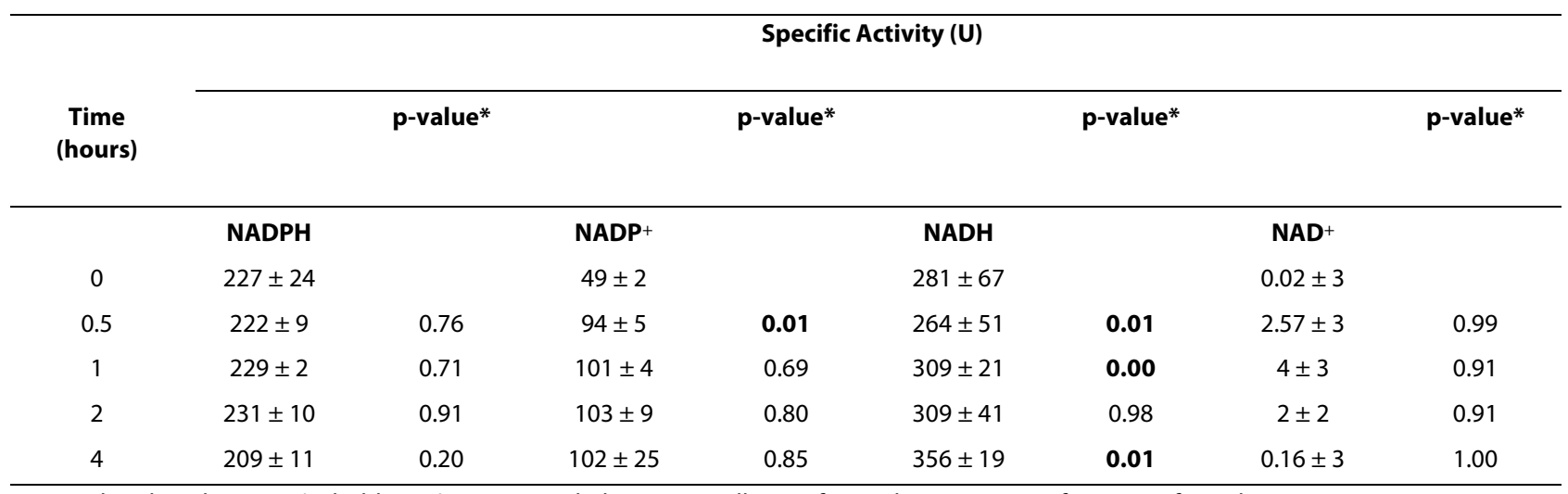

*P-values less than 0.05 (in bold print) were regarded as statistically significant changes in specific activity from the previous time point.

encoded by msmeg_6272 and has an approximate subunit size of $118 \mathrm{kDa}$ [43]. This enzyme may fall into the 115 $\mathrm{kDa}$ class of large GDH's, however the presence of a functional protein is yet to be shown. Under our experimental conditions, the total $\mathrm{NAD}^{+}-\mathrm{GDH}$ deaminating reaction activity was very low and did not notably alter in response to changing ammonium concentrations (Figure 2D) nor to prolonged ammonium starvation conditions (Table 1). This observation may be attributable to the very low glutamate affinity of the $\mathrm{L}_{-} 180$ class of $\mathrm{NAD}^{+-} \mathrm{GDH}$ (MSMEG_4699) [29]. In contrast, the NAD+-GDH aminating reaction activity was much higher and was significantly changed by ammonium availability (Figure $2 \mathrm{C}$ ). During nitrogen starvation, the total $\mathrm{NAD}^{+}-\mathrm{GDH}$ aminating activity tended to increase (a 14\% increase between 0.5 and $1 \mathrm{hrs}, \mathrm{p}=0.00$, Table 1 ) and remained elevated but relatively constant throughout the ammonium starvation time course study (Table 1), presumably in order to assist nitrogen assimilation under these conditions. In response to an ammonium pulse, the total $\mathrm{NAD}^{+-} \mathrm{GDH}$ aminating activity was reduced almost 2 fold $(\mathrm{p}=0.00$, data not shown; Figure $2 \mathrm{C}, \mathbf{\square})$. This decrease in activity may be due to the presence of a constitutively active $\mathrm{NADP}^{+}-\mathrm{GDH}$ which could adequately assimilate nitrogen under these conditions. In $M$. smegmatis, it would appear that at least one of the possible $\mathrm{NAD}^{+}$ GDH enzymes plays a largely anabolic or aminating role, which is in contrast with the opinion that $\mathrm{NAD}^{+-G D H}$ enzymes are normally involved in glutamate catabolism $[12,13]$. In addition, it would appear that at least one of the NAD+-GDH enzymes present in M. smegmatis is regulated in response to nitrogen availability. It may be that the regulation of $\mathrm{NAD}^{+-} \mathrm{GDH}$ activity in response to nitrogen availability may be due to the interaction of nonphosphorylated GarA with the enzyme under conditions of nitrogen excess and this interaction may be abolished by pknG mediated phosphorylation of GarA under conditions of nitrogen starvation.

\section{Glutamine synthetase specific activity in response to ammonium limitation and excess}

The activity of the high ammonium affinity GS enzyme was assessed using the $\gamma$-glutamyl transferase assay [44]. Upon exposure to nitrogen limitation, M. smegmatis GS activity increased significantly $(\mathrm{p}=0.01)$ within $0.5 \mathrm{hrs}$ and continued to increase significantly after $1 \mathrm{hr}$ of nitrogen starvation (Table 2) to reach a final activity at $4 \mathrm{hrs}$ that was approximately 2.5 fold greater than at zero hours (Table 2). When an ammonium pulse was applied to nitrogen starved cells, GS activity decreased significantly ( 0.66 fold reduction, $\mathrm{p}=0.00$, Table 2 ) within $1 \mathrm{hr}$ of exposure to nitrogen excess. Our results are in accordance with studies done in a variety of bacteria, including M. tuberculosis, which have shown that GS activity is upregulated (approximately 3.7 fold in $M$. tuberculosis [45]) in response to nitrogen limitation and conversely regulated in response to nitrogen excess $[45,46]$. In $M$. tuberculosis, this regulation is achieved by post-translational adenylylation of GS $[3,45]$, and transcriptional control [47]. These results indicate that, under our experimental conditions, $M$. smegmatis did sense $3 \mathrm{mM}\left(\mathrm{NH}_{4}\right)_{2} \mathrm{SO}_{4}$ as a nitrogen starvation condition since GS activity was upregulated, most likely in order to scavenge ammonium from the environment. In addition, $60 \mathrm{mM}\left(\mathrm{NH}_{4}\right)_{2} \mathrm{SO}_{4}$ was perceived as a condition of nitrogen sufficiency, as GS activity was down-regulated in order to prevent a futile energy depleting cycle.

\section{Relative quantification of gene transcription}

The response to nitrogen availability at the mRNA level of genes encoding for GS $(g \ln A 1), \mathrm{NADP}^{+-\mathrm{GDH}}$ (msmeg_5442) and the L_180 NAD+-GDH (msmeg_4699) was assessed by semi-quantitative Real-Time PCR [48]. 
Table 2: Glutamine synthetase specific activities determined by the $\gamma$-glutamyl transferase assay when $M$. smegmatis was exposed to conditions of nitrogen limitation $\left(3 \mathrm{mM}\left(\mathrm{NH}_{4}\right)_{2} \mathrm{SO}_{4}\right)$ and nitrogen excess $\left(60 \mathrm{mM}\left(\mathrm{NH}_{4}\right)_{2} \mathrm{SO}_{4}\right)$.

\begin{tabular}{|c|c|c|c|}
\hline $\begin{array}{c}\text { (NH4)2SO4 Concentration } \\
\text { (mM) }\end{array}$ & Time (hours) & Specific activity (U) & p-value* \\
\hline \multirow[t]{5}{*}{$3 \mathrm{mM}$} & 0 & $45 \pm 17$ & \\
\hline & 0.5 & $57 \pm 12$ & 0.01 \\
\hline & 1 & $63 \pm 12$ & 0.27 \\
\hline & 2 & $78 \pm 16$ & 0.00 \\
\hline & 4 & $103 \pm 17$ & 0.00 \\
\hline \multirow[t]{3}{*}{$60 \mathrm{mM}$} & 0 & $76 \pm 2$ & \\
\hline & 0.5 & $50 \pm 1$ & 0.00 \\
\hline & 1 & $47 \pm 5$ & 0.08 \\
\hline
\end{tabular}

* The $p$-values given show the statistical significance of the change in GS specific activity between time points. $p<0.05$ (in bold) was regarded as a statistically significant change in specific activity from the previous time point.

The relative change in gene expression was calculated as a ratio of target gene transcription versus the transcription of $\operatorname{sig} A$, as an internal control.

A significant up-regulation (factor of $2 \pm 0.5, \mathrm{p}=0.001$, Table 3) of $g \ln A 1$ gene transcription was observed within $0.5 \mathrm{hrs}$ exposure to nitrogen starvation and continued to increase significantly thereafter (Table 3). This was an expected result as similar increases have been reported in M. smegmatis [49]. Within the first hour, the increase in gene transcription was relatively low which indicated that the requirement for the synthesis for additional GS protein was not very high. It has previously been reported that a surprisingly large quantity of GS is produced by $M$. tuberculosis and is exported to the extracellular milieu [23]. Although M. smegmatis does not export GS [23], it may be that, similar to $M$. tuberculosis, a large intracellular pool of GS is present whose activity could be up-regulated via de-adenylylation by $G \ln E$ [45] and thereby satisfy the need for ammonium assimilation under these conditions. After $2 \mathrm{hrs}$ exposure to nitrogen starvation, there was a profound increase in $g \ln A 1$ transcription (67 \pm 38 , Table 3 ) which may reflect a heightened state of intracellular nitrogen starvation and thus the requirement for increased levels of GS enzyme in order to efficiently assimilate ammonium under these conditions. The relatively constant increase in GS activity under the same conditions (Table 2) was most likely due a combination of an increase in $g \ln A 1$ transcription and very strict control of GS activity by the adenylyltransferase, GlnE, in order to balance ammonium assimilation; energy expenditure and the intracellular glutamate/glutamine ratios. When an ammonium pulse was applied to M. smegmatis that had been starved of nitrogen, a down-regulation in transcription was observed, however, it was not found to be statistically significant (data not shown). There was, however, a rapid and significant decrease in GS specific activity when the bacteria were exposed to an ammonium pulse (Table 2) which suggests that post-translational modification via GlnE is responsible for the swift response in GS activity to changing ammonium concentrations.

Within the first hour of nitrogen limitation, the transcription of both msmeg 5442 and msmeg 4699 was statistically significantly down-regulated by a relative factor of 2.00 (calculated by 1 /expression ratio). The expression of msmeg_5442 did not alter significantly thereafter (Table 3). The down-regulation of NADP+-GDH (msmeg_5442) observed in M. smegmatis is similar to the pattern of expression of the homologous gene (SCO4683) in a related Actinomycete, Streptomyces coelicolor, under analogous conditions [50]. The L_180 class of NAD+_ GDH enzymes identified to date have been well characterised, however, the expression of the genes encoding these enzymes has not yet been investigated in any depth. Under our experimental conditions, the L_180 NAD ${ }^{+}$ $\mathrm{GDH}$ in $M$. smegmatis (msmeg 4699) was down-regu- 
Table 3: Relative quantification ${ }^{a}$ of the expression of GS (glnA1), NADP-GDH (msmeg_5442) and L_180 NAD-GDH (msmeg_4699) when M. smegmatis was exposed to prolonged periods of nitrogen limitation.

\begin{tabular}{|c|c|c|c|c|c|c|}
\hline \multirow[t]{2}{*}{ Time (hours) } & \multicolumn{5}{|c|}{ Gene } & \multirow[b]{2}{*}{ P-value } \\
\hline & $g \ln A 1$ & P-value & MSMEG_4699 & P-value & MSMEG_5442 & \\
\hline 0.5 & $2 \pm 0.5$ & 0.001 & $0.5 \pm 0.1$ & 0.001 & $0.5 \pm 0.1$ & 0.001 \\
\hline 1 & $3 \pm 0.6$ & 0.001 & $0.6 \pm 0.05$ & 0.001 & $0.5 \pm 0.08$ & 0.001 \\
\hline 4 & $58 \pm 43$ & 0.001 & $18 \pm 15$ & 0.001 & $3 \pm 3$ & 0.272 \\
\hline
\end{tabular}

a The relative change in gene expression when $M$. smegmatis was exposed to nitrogen starvation was compared to gene expression after $M$. smegmatis exposed to $60 \mathrm{mM}\left(\mathrm{NH}_{4}\right)_{2} \mathrm{SO}_{4}$ for 1 hours (time point zero). SigA was used as the internal reference gene. Values $>1$ reflect an upregulation of gene expression whereas values $<1$ represent a down-regulation of expression in relation to the non-regulated internal reference, sigA.

* statistically significant gene regulation $(p<0.05)$

lated within the first hour of nitrogen starvation (Table 3). However, after 2 hrs exposure to nitrogen starvation conditions, there was a statistically significant increase in msmeg 4699 transcription (factor of $13 \pm 4, \mathrm{p}=0.001$, Table 3). The expression of the putative NAD+-GDH gene, encoded by msmeg_6272, was also analysed but by reverse transcriptase PCR. The PCR products were separated on a $1 \%$ agarose gel which were quantified using densitometric analysis of the gel image [51]. An msmeg_6272 mRNA species was detected (Figure 3) which indicated that the gene was transcribed under our experimental conditions. In addition, from visual inspection of the gel image (Figure 3), msmeg_6272 appeared to be regulated in response to nitrogen availability. Upon densitometric analysis, it was found that after an initial 2 fold decrease in gene expression (Table 4) in response to nitrogen starvation, gene transcription appeared to be up-regulated after 2 hrs (approximately 2 fold, Table 4) exposure to these conditions.

Transcriptional control of nitrogen-related genes in $S$. coelicolor is co-ordinated by an OmpR-type regulator, GlnR, which can act both as an activator and repressor of

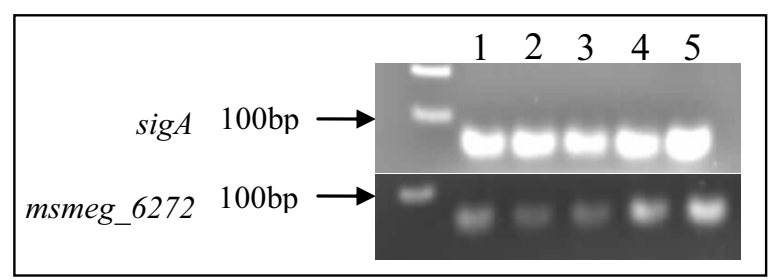

Figure 3 Reverse transcriptase PCR of $m s m e g \_6272$ cultured under conditions of nitrogen starvation $\left(3 \mathrm{mM}\left(\mathrm{NH}_{4}\right)_{2} \mathrm{SO}_{4}\right)$ for four hours. Lane (1) $0 \mathrm{hr}$ at which point $\mathrm{M}$. smegmatis was exposed to nitrogen excess $\left(60 \mathrm{mM}\left(\mathrm{NH}_{4}\right)_{2} \mathrm{SO}_{4}\right)$ for $1 \mathrm{hr}$ (2) $0.5 \mathrm{hr}$ nitrogen starvation; (3) $1 \mathrm{hr}$ nitrogen starvation (4) $2 \mathrm{hrs} \mathrm{nitrogen} \mathrm{starvation} \mathrm{and} \mathrm{(5)} 4 \mathrm{hrs} \mathrm{nitro-}$ gen starvation. SigA was amplified as an unregulated internal control. transcription [50,52]. A GlnR-type regulator has been identified in M. smegmatis and has been shown to regulate a number of nitrogen-related genes in this organism[49]. Amon et al. [49] were able to elucidate a GlnR consensus DNA binding sequence, however, this binding sequence could not be identified upstream of msmeg_5442 [49] and has not been investigated with regards to msmeg_4699 or msmeg_6272. The M. smegmatis genome also encodes for a putative TetR-type transcriptional repressor, AmtR, which is responsible for the regulation of a number of genes involved in nitrogen metabolism in C. glutamicum [53]. The gene encoding for $\mathrm{NADP}^{+}-\mathrm{GDH}$ in C. glutamicum is up-regulated in response to nitrogen starvation, however, it was found that the transcription of this gene is highly variable and is controlled by a variety of regulators [10] including AmtR. It is possible that either of these regulators may be responsible for the regulation of msmeg_5442; msmeg_6272 and msmeg_4699 transcription in M. smegmatis, however, this remains to be investigated.

The observed transcriptional regulation of the gene encoding for $\mathrm{NADP}^{+-G D H}$ (msmeg_5442) did not directly correlate with observations made at the level of GDH specific activity. An initial down-regulation of msmeg_5442 gene transcription was seen under conditions of nitrogen starvation (Table 3), yet NADP+-GDH reaction activity increased (Figure $2 \mathrm{~B}$ ). This result suggests that an additional regulatory mechanism may play a role in the control of total NADP+-GDH enzyme activity. A slightly different trend was observed for $\mathrm{NAD}^{+-} \mathrm{GDH}$ under conditions of nitrogen starvation. The expression of msmeg_6272 and msmeg_4699 was repressed within the first hour of nitrogen starvation (Table 4) which was reflected by an initial decrease in $\mathrm{NAD}^{+-} \mathrm{GDH}$ specific activity. However, between $0.5 \mathrm{hr}$ and $1 \mathrm{hr}$ nitrogen starvation, there was a significant increase in $\mathrm{NAD}^{+-} \mathrm{GDH}$ 
Table 4: Relative quantification of $\mathbf{m s m e g} 6272$ by reverse transcriptase PCR under conditions of nitrogen limitation (3 $\left.\mathrm{mM}\left(\mathrm{NH}_{4}\right)_{2} \mathrm{SO}_{4}\right)$ and excess $\left(60 \mathrm{mM}\left(\mathrm{NH}_{4}\right)_{2} \mathrm{SO}_{4}\right)$.

\begin{tabular}{|c|c|c|}
\hline Culture condition & Time (hrs) & $\begin{array}{l}\text { Fold Increase }(+) \text { or Decrease }(-) \text { in } \\
\text { expression }\end{array}$ \\
\hline \multirow[t]{4}{*}{$3 \mathrm{mM}(\mathrm{NH} 4) 2 \mathrm{SO}$} & 0.5 & -- \\
\hline & 1 & no change \\
\hline & 2 & ++ \\
\hline & 4 & no change \\
\hline $60 \mathrm{mM}$ (NH4)2SO4 & 0.5 & no change \\
\hline
\end{tabular}

specific activity in the absence of an increase in transcription of either msmeg_4699 or msmeg_6272 (Table 3 and 4). After 2 hrs exposure to nitrogen starvation conditions, the expression of msmeg_4699 and msmeg_6272 increased significantly (by a factor of approximately 5 and 2 , respectively, Table 3 ) which, once again, was mirrored by an increase in specific activity of $\mathrm{NAD}^{+-} \mathrm{GDH}$ by approximately $50 \mathrm{U}$ (Table 1 ). These observations suggest that NAD+-GDH activity may be regulated by both transcriptional control and an additional regulatory mechanism such as post-translational modification.

\section{Conclusion}

The production of glutamate and glutamine is critically important in all bacteria for the synthesis of essential cellular components. Glutamate can be produced by either GOGAT or GDH and glutamine is produced by glutamine synthetase via the GS/GOGAT cycle. The large energy cost associated with the production of glutamate and glutamine by the GS/GOGAT system can be bypassed by the functioning of the GDH pathway (if present) under conditions of nitrogen excess. Conversely, under nitrogen limiting conditions, the GS/GOGAT cycle becomes the major nitrogen assimilatory route (for review see [54]). Our analysis of $M$. smegmatis GS found that both enzyme specific activity and $g \ln A 1$ transcription were regulated in response to nitrogen availability. GS specific activity was rapidly down-regulated under excess ammonium concentrations and conversely regulated when starved of ammonium. This rapid change in activity, in the absence of initial significant transcriptional regulation, could be attributed to post-translational control by GlnE. The large increase in $g \ln A 1$ transcription after a prolonged period of nitrogen starvation ( 2 to $4 \mathrm{hrs}$ ammonium starvation) could, together with posttranslational regulation, be responsible for further increases in GS activity under those conditions. GS appeared to play a greater assimilatory role under conditions of nitrogen limitation than under conditions of nitrogen excess which is similar to observations made in other bacteria [46].

Under our experimental conditions, we observed that $\mathrm{NADP}^{+-} \mathrm{GDH}$ aminating activity did not alter significantly in response to nitrogen availability, in contrast to results obtained in related Actinomycetes such as $S$. coelicolor [55] or C. glutamicum [36]. It appeared as though $\mathrm{NADP}^{+}-\mathrm{GDH}$ in $M$. smegmatis had a constitutive ammonium assimilatory function under our experimental conditions. It was found, however, that the de-aminating activity of NADP+-GDH did change in response to nitrogen availability which suggests that the activity of $\mathrm{NADP}^{+}-\mathrm{GDH}$ in $\mathrm{M}$. smegmatis is regulated in a manner different to other Actinomycetes. It may be that an increase in glutamate catabolism under these conditions could produce free ammonia required for essential glutamine production by GS. The high levels of $\mathrm{NAD}^{+-} \mathrm{GDH}$ aminating activity observed under all conditions of ammonium availability in $M$. smegmatis was unexpected as $\mathrm{NAD}^{+-G D H}$ enzymes are presumed to be largely involved in glutamate catabolism. In addition, $\mathrm{NAD}^{+-}$ GDH animating activity appeared to change in response to nitrogen availability which could indicate an important role in ammonium assimilation. In the absence of an initial upregulation of $\mathrm{NAD}^{+-} \mathrm{GDH}$ gene transcription under conditions of ammonium starvation, the observed increase in $\mathrm{NAD}^{+-} \mathrm{GDH}$ aminating activity might possibly be attributed to other control mechanisms, such as the GarA-pknG regulatory system. This type of regulation may also account for the observed decrease in $\mathrm{NAD}^{+}$ GDH aminating activity upon exposure to an ammonium pulse. Transcription of msmeg_4699 and msmeg_6272 increased after prolonged exposure to nitrogen starvation ( 2 to 4 hrs ammonium starvation), which similarly to GS, 
could contribute to the maintenance of elevated levels of activity under those conditions. An inherent limitation of this study is that cell free extracts were used in enzyme activity assays which may possibly contain enzymes/proteins other than the glutamate dehydrogenases that could utilize $\mathrm{NAD}(\mathrm{P}) \mathrm{H}$ as co-factors and therefore confound GDH assay results. However, since whole cell lysates have been utilized successfully in previous studies $[10,37,56]$, the possibility that the observed changes in enzyme activity are true physiological responses to nitrogen availability should not be disregarded.

From our results, it would appear that there are differences in the roles that the various GDH enzymes play in $M$. smegmatis and in other related organisms. There are also differences between the mycobacteria. The slow growing pathogenic mycobacteria such as $M$. tuberculosis and $M$. bovis do not appear to have an $\mathrm{NADP}^{+}-\mathrm{GDH}$, however both genomes do encode for an NAD+-GDH which share a $81 \%$ and $82 \%$ amino acid identity with MSMEG_4699 respectively. The results obtained from our study imply that $\mathrm{NAD}^{+}-\mathrm{GDH}$ may play a previously unpredicted and potentially important nitrogen assimilatory role in these pathogenic species. Since NAD ${ }^{+-G D H}$ enzymes are able to assimilate nitrogen with a much lower associated energy cost than the GS/GOGAT system, it is possible that these enzymes may facilitate bacterial survival under conditions where energy preservation is vital, such as during latency. An investigation into the physiological roles of $\mathrm{NAD}^{+-} \mathrm{GDH}$ enzyme in $M$. bovis is currently underway.

\section{Methods}

\section{Bacterial strains and culture methods}

Mycobacterium smegmatis MC1552 was routinely cultured in 7H9 medium (Difco) supplemented with 10\% Oleic acid-Albumin-Dextrose-Catalase enrichment (OADC; Middlebrook) until an $\mathrm{OD}_{600}$ of approximately 0.8 . The bacteria were transferred to Kirchner's minimal medium [57] in which asparagine was replaced with ammonium sulphate $\left(\left(\mathrm{NH}_{4}\right)_{2} \mathrm{SO}_{4}\right)$ as the sole nitrogen source. It has previously been shown that an increase in $\mathrm{NH}_{4}{ }^{+}$concentration from $3.8 \mathrm{mM}$ to $38 \mathrm{mM}$ caused a 10fold reduction in $M$. tuberculosis activity [23]. The observed response of GS activity to the change in $\mathrm{NH}_{4}{ }^{+}$ concentration is indicative that bacteria exposed to 3.8 $\mathrm{mM} \mathrm{NH}{ }_{4}{ }^{+}$were starved of nitrogen. In addition to a change in activity, a response in the level of GS transcription was also observed [47]. An $\left(\mathrm{NH}_{4}\right)_{2} \mathrm{SO}_{4}$ concentration of $3 \mathrm{mM}$ was thus used to induce nitrogen starvation in M. smegmatis whereas Kirchner's medium containing 60 $\mathrm{mM}\left(\mathrm{NH}_{4}\right)_{2} \mathrm{SO}_{4}$ was considered as nitrogen sufficiency or excess. M. smegmatis liquid cultures were maintained at $37^{\circ} \mathrm{C}$ with shaking.

\section{Preparation of crude protein extract}

M. smegmatis was harvested by centrifugation and resuspended in $1 \mathrm{ml}$ of Tris- $\mathrm{HCl}(\mathrm{pH} 8)$ or phosphate buffer $\left(\mathrm{Na}_{2} \mathrm{H}_{2} \mathrm{PO}_{4} / \mathrm{K}_{2} \mathrm{HPO}_{4} ; \mathrm{pH}\right.$ 7.0). The cells were disrupted by ribolysing at maximum speed for $20 \mathrm{sec}$ (Fastprep FP120, Bio101 Savant) and immediately placed on ice for $1 \mathrm{~min}$ thereafter. This ribolysing procedure was repeated 3 to 4 times with intermittent cooling on ice. The sample was centrifuged at $4^{\circ} \mathrm{C}$ in a benchtop centrifuge (Mikro 200, Hettich Zentrifugen) to remove insoluble material and the total protein concentration was determined using the Bradford assay (Bio-Rad, Germany) according to the manufacturer's instructions.

\section{Enzyme assays}

\section{Glutamate dehydrogenase activity assays}

\section{i) NADPH-specific Glutamate dehydrogenase}

NADPH-GDH activity was assayed essentially as described by Sarada et al. [28]. The NADPH-GDH forward reaction (reductive aminating activity) was assayed by preparation of a $1 \mathrm{ml}$ reaction system containing 100 $\mathrm{mM}$ Tris $\mathrm{HCl}$ (pH 8.0), $100 \mathrm{mM} \mathrm{NH}_{4} \mathrm{Cl} ; 10 \mathrm{mM} \alpha$-ketoglutarate and $0.1 \mathrm{mM}$ NADPH. The NADPH-GDH reverse reaction (oxidative deaminating activity) assay preparation consisted of $100 \mathrm{mM}$ Tris- $\mathrm{HCl}$ (pH 9.0); $200 \mathrm{mM}$ glutamate and $0.1 \mathrm{mM} \mathrm{NADP}^{+}$. The reactions were initiated by the addition of $10 \mu \mathrm{g} M$. smegmatis crude protein extract.

ii) NADH-specific GDH The activity of both the forward and reverse NADH-GDH reactions were assayed using a combination of methods from Loyola-Vargas $e t$ al. [56] and Miñambres et al.[18]. The $1 \mathrm{ml} \mathrm{NADH-GDH}$ forward reaction (reductive amination) assay consisted of $100 \mathrm{mM}$ Phosphate buffer $\left(\mathrm{HK}_{2} \mathrm{PO}_{4} / \mathrm{H}_{2} \mathrm{NaPO}_{4} ; \mathrm{pH}\right.$ 7.0); $100 \mathrm{mM} \mathrm{NH}_{4} \mathrm{Cl} ; 10 \mathrm{mM} \alpha$-ketoglutarate and $0.16 \mathrm{mM}$ $\mathrm{NADH}$. The $1 \mathrm{~mL}$ reverse reaction assay (oxidative deamination) was prepared by adding $100 \mathrm{mM}$ Phosphate buffer ( $\mathrm{pH}$ 7.0); $100 \mathrm{mM}$ L-glutamate; and $2 \mathrm{mM} \mathrm{NAD}^{+}$. The assay reactions were initiated by the addition of $10 \mu \mathrm{g} M$. smegmatis crude protein extract.

The forward or aminating reactions were assayed by measuring the oxidation of NADPH or NADH spectrophotometrically at $340 \mathrm{~nm}$. The reverse or deaminating reactions were assayed by measuring the reduction of $\mathrm{NADP}^{+}$or $\mathrm{NAD}^{+}$at $340 \mathrm{~nm}$. Specific enzyme activities were calculated using the $\mathrm{NAD}(\mathrm{P}) \mathrm{H}$ extinction co-efficient of $6.22 \mathrm{~cm}^{2} / \mu$ mole. One unit of enzyme activity was defined as 1 nmole of coenzyme $(\mathrm{NAD}(\mathrm{P}) \mathrm{H})$ oxidized or reduced per minute, per milligram protein added. A two- 
way ANOVA using a mixed model with the correct nested terms was used to analyse the data.

\section{Glutamine synthetase activity assay}

Total GS activity was assayed using the $\gamma$-glutamyl-transferase assay as described elsewhere [58]. Briefly, total GS activity was assayed in the presence of $0.3 \mathrm{mM} \mathrm{Mn}^{2+}$ as the activity of both adenylylated and de-adenylylated forms of GS are measured under these conditions. The reaction was initiated by the addition of $10 \mu \mathrm{g} M$. smegmatis crude protein extract and allowed to proceed for 30 $\min$ at $37^{\circ} \mathrm{C}$. The reaction was halted by the addition of a stop mix $\left(1 \mathrm{M} \mathrm{FeCl}_{3} \cdot 6 \mathrm{H}_{2} \mathrm{O}, 0.2 \mathrm{M}\right.$ Trichloroacetic acid and $7.1 \% \mathrm{v} / \mathrm{v} \mathrm{HCl}$ ) and the samples were briefly centrifuged in order to remove any precipitate that may have formed. The production of $\gamma$-glutamylhydroxamate was determined by measuring the absorbance at $540 \mathrm{~nm}$. One unit of enzyme activity was defined as the amount of enzyme producing $1 \mu$ mole $\gamma$-glutamylhydroxamate $/ \mathrm{min} /$ $\mathrm{mg}$ protein in the transfer reaction. A technical replicate of each enzyme assay was measured and each experiment was repeated at least three times. A two-way ANOVA using a mixed model with the correct nested terms was used to analyse the data.

\section{RNA preparation}

M. smegmatis cells were collected by centrifugation (Eppendorf Centrifuge 5810R) and resuspended in $1 \mathrm{ml}$ Trizol (Invitrogen). The cell suspension was ribolysed (Fastprep FP120, Bio101 Savant) in a $2.0 \mathrm{ml}$ screw cap microtube (Quality Scientific Plastics) containing $0.5 \mathrm{~mm}$ glass beads at a maximum speed setting of 6.0 for $20 \mathrm{sec}$ onds. The tubes were immediately placed on ice for 1 minute to dissipate the heat caused by friction during the ribolyzing process. This homogenisation step was repeated 3-4 times and the cooled homogenate was incubated at room temperature for 5 minutes to allow dissociation of nucleoprotein complexes. A total of $250 \mu \mathrm{l}$ chloroform was added to the mixture which was rapidly inverted for the first 20 seconds, and then periodically thereafter for a further 5 minutes at room temperature. The samples were centrifuged at $18630 \times \mathrm{g}\left(4^{\circ} \mathrm{C}\right)$ for 10 min and the aqueous phase removed. Two volumes of ice-cold $100 \%$ ethanol was added to the supernatant, mixed by inversion and incubated at $-20^{\circ} \mathrm{C}$ overnight to allow nucleic acid precipitation. RNA was collected by centrifugation at $18630 \times \mathrm{g}\left(4^{\circ} \mathrm{C}\right)$, washed with $70 \%$ ethanol and resuspended in water. Any contaminating DNA was removed by DNase digestion (Turbo-DNase, Ambion) according to the manufacturer's instructions. Quality and quantification of total bacterial mRNA extracted was assessed using the Experion system (Experion RNA Standard Sense Kit, Bio-Rad).

Complementary DNA was synthesised from $1 \mu \mathrm{g}$ total RNA using the Transcriptor First Strand cDNA Synthesis Kit (Roche) and random hexamer primers (supplied) according to manufacturer's instructions.

\section{Real-time and reverse-transcriptase PCR}

Real-Time PCR reactions were performed in the LightCycler version 1.5 (Roche Diagnostics) using either the LightCycler Master ${ }^{\text {Plus }}$ SYBR Green (Roche) or the Master SYBR Green kit (Roche). PCR master mixes (SYBR Green dye and FastStart Taq DNA polymerase were supplied) were prepared according to the manufacturer's instructions. A four step experimental protocol was used: (i) activation $\left(95^{\circ} \mathrm{C}\right.$ for $\left.15 \mathrm{~min}\right)$ (ii) amplification step repeated for 45 cycles $\left(95^{\circ} \mathrm{C}\right.$ for $10 \mathrm{sec}$; primer-specific $\mathrm{Tm}$ for $10 \mathrm{sec}, 72^{\circ} \mathrm{C}$ for $10 \mathrm{sec}$ with a single fluorescence measurement) (iii) melting curve analysis $\left(65^{\circ} \mathrm{C}-95^{\circ} \mathrm{C}\right.$ with a heating rate of $0.1^{\circ} \mathrm{C}$ per second and a continuous fluorescence measurement) (iv) cooling step down to $40^{\circ} \mathrm{C}$ (see Table 1 for annealing temperatures). Refer to Table 5 for a complete list of primer sequences used to analyse the genes of interest. RNA template and no-template controls were included to determine DNA contamination of RNA samples or PCR reactions. All PCR

Table 5: Primer sequences used for the relative quantification of glutamine synthetase and glutamate dehydrogenase genes.*

\begin{tabular}{ccccc}
\hline Gene & Sense Primer (5'-3') & Antisense Primer (5'-3') & Product size (bp) & $\begin{array}{c}\text { Annealing } \\
\left.\text { Temperature ( }{ }^{\circ} \mathbf{C}\right)\end{array}$ \\
\hline glnA1 & ATGTGCTGCTGTTCAAGT & TGAAGGTGACGGTCTTGC & 66 & 55 \\
sigA & GACTCGGTTCGCGCCTA & CCTCTTCTTCGGCGTTG & 64 & 55 \\
msmeg_6272 & TGATCCGCCACATCCTG & GATGTAGGTGCCGATGC & 65 & 56.5 \\
msmeg_5442 & AGATCATGCGGTTCTGTC & GTGTATTCACCGATGTGCC & 61 & 55 \\
\hline
\end{tabular}

*The product size and annealing temperatures are also given. sigA was used as an internal control or housekeeping gene. Reverse transcriptase PCR reactions were carried out in the GeneAmp PCR System 9700 
reactions as well as all biological experiments were done in triplicate. Relative quantification of gene expression was done using the REST-384 Version 1 software with PCR efficiency correction for individual real-time PCR transcripts [48]. SigA was used as the internal standard to normalise target gene expression levels in each RNA sample [59] as it has been shown that sigA expression remains constant under various growth and stress conditions [60].

Reverse transcriptase PCR reactions were carried out in the GeneAmp PCR System 9700 (Applied Biosystems) using HotStar Taq DNA Polymerase (Qiagen) according to manufacturer's instructions. A $1 / 100$ dilution of the cDNA was made and equal volumes $(2 \mu \mathrm{l})$ were used in each PCR reaction. The PCR protocol was initiated by an activation step of $15 \mathrm{~min}$ at $95^{\circ} \mathrm{C}$. This was followed by 35 cycles of: denaturation $\left(95^{\circ} \mathrm{C}\right.$ for $\left.30 \mathrm{sec}\right)$, primer annealing $(\mathrm{Tm}$ specific for $30 \mathrm{sec})$ and elongation $\left(72^{\circ} \mathrm{C}\right.$ for 30 sec). A final DNA polymerisation step at $72^{\circ} \mathrm{C}$ for $10 \mathrm{~min}$ followed by cooling to $4^{\circ} \mathrm{C}$ was included. Densitometric analysis of gel images (Un-Scan-It gel Automated Digitizing System, Version 5.1) was used to quantify gene expression [51].

\section{Authors' contributions}

$\mathrm{CJH}$ conceived of the study, performed the enzyme assays, transcriptional studies and drafted the manuscript. DH was involved in the study design and participated in glutamine synthetase assays. MK did all statistical analyses on acquired data. IW participated in the design of the study, contributed to the analysis of the data and revision of the manuscript. PvH was involved in the interpretation of the data and critical revision of the manuscript. All authors have read the manuscript and approved the final product.

\section{Acknowledgements}

The authors thank the University of Stellenbosch, the South African Medical Research Council and the South African National Research Foundation for both the funding of the authors and of the study as a whole.

\section{Author Details}

'DST/NRF Centre of Excellence for Biomedical TB Research, Department of Molecular Biology and Human Genetics, Faculty of Health Sciences, University of Stellenbosch, P.O.Box 19063, Tygerberg, South Africa and ${ }^{2}$ Centre for Statistical Consultation, Dept of Statistics and Actuarial Sciences University of Stellenbosch Private Bag X1, Matieland, South Africa

Received: 27 January 2010 Accepted: 11 May 2010 Published: 11 May 2010

\section{References}

1. Reitzer L: Nitrogen assimilation and global regulation in Escherichia coli. Annu Rev Microbiol 2003, 57:155-176.

2. Fisher SH: Regulation of nitrogen metabolism in Bacillus subtilis: vive la difference! Mol Microbiol 1999, 32:223-232.

3. Parish T, Stoker NG: glnE is an essential gene in Mycobacterium tuberculosis. J Bacterio/ 2000, 182:5715-5720.

4. Fink D, Falke D, Wohlleben W, Engels A: Nitrogen metabolism in Streptomyces coelicolor A3(2): modification of glutamine synthetase I by an adenylyltransferase. Microbiology 1999, 145(Pt 9):2313-2322.

5. Schulz AA, Collett HJ, Reid SJ: Nitrogen and carbon regulation of glutamine synthetase and glutamate synthase in Corynebacterium glutamicum ATCC 13032. FEMS Microbiol Lett 2001, 205:361-367.

6. Britton KL, Baker PJ, Rice DW, Stillman TJ: Structural relationship between the hexameric and tetrameric family of glutamate dehydrogenases. Eur J Biochem 1992, 209:851-859.
7. Duncan PA, White BA, Mackie RI: Purification and properties of NADPdependent glutamate dehydrogenase from Ruminococcus flavefaciens FD-1. Appl Environ Microbiol 1992, 58:4032-4037.

8. Antonopoulos DA, Aminov RI, Duncan PA, White BA, Mackie RI: Characterization of the gene encoding glutamate dehydrogenase (gdhA) from the ruminal bacterium Ruminococcus flavefaciens FD-1. Arch Microbiol 2003, 179:184-190.

9. Schwacha A, Bender RA: The product of the Klebsiella aerogenes nac (nitrogen assimilation control) gene is sufficient for activation of the hut operons and repression of the gdh operon. J Bacteriol 1993, 175:2116-2124

10. Hanssler E, Muller T, Palumbo K, Patek M, Brocker M, Kramer R, Burkovski A: A game with many players: control of gdh transcription in Corynebacterium glutamicum. J Biotechnol 2009

11. Camarena L, Poggio S, Garcia N, Osorio A: Transcriptional repression of gdhA in Escherichia coli is mediated by the Nac protein. FEMS Microbiol Lett 1998, 167:51-56.

12. Miller SM, Magasanik B: Role of NAD-linked glutamate dehydrogenase in nitrogen metabolism in Saccharomyces cerevisiae. J Bacteriol 1990, 172:4927-4935.

13. Consalvi V, Chiaraluce R, Politi L, Vaccaro R, De RM, Scandurra R: Extremely thermostable glutamate dehydrogenase from the hyperthermophilic archaebacterium Pyrococcus furiosus. Eur J Biochem 1991, 202:1189-1196.

14. Rice DW, Hornby DP, Engel PC: Crystallization of an NAD+-dependent glutamate dehydrogenase from Clostridium symbiosum. $\mathrm{J} \mathrm{Mol} \mathrm{Biol}$ 1985, 181:147-149.

15. Chavez S, Candau P: An NAD-specific glutamate dehydrogenase from cyanobacteria. Identification and properties. FEBS Lett 1991, 285:35-38.

16. Stuart Shapiro: Reglation of Secondary Metabolism in Actinomycetes. CRC Press inc; 1989:35-38. Ref Type: Generic

17. Veronese FM, Nyc JF, Degani Y, Brown DM, Smith EL: Nicotinamide adenine dinucleotide-specific glutamate dehydrogenase of Neurospora. I. Purification and molecular properties. J Biol Chem 1974 249:7922-7928.

18. Minambres $B$, Olivera ER, Jensen RA, Luengo JM: A new class of glutamate dehydrogenases $(\mathrm{GDH})$. Biochemical and genetic characterization of the first member, the AMP-requiring NAD-specific GDH of Streptomyces clavuligerus. J Biol Chem 2000, 275:39529-39542.

19. Kawakami R, Sakuraba H, Ohshima T: Gene cloning and characterization of the very large NAD-dependent l-glutamate dehydrogenase from the psychrophile Janthinobacterium lividum, isolated from cold soil. J Bacteriol 2007, 189:5626-5633.

20. Lu CD, Abdelal AT: The gdhB gene of Pseudomonas aeruginosa encodes an arginine-inducible $\mathrm{NAD}(+)$-dependent glutamate dehydrogenase which is subject to allosteric regulation. $J$ Bacteriol 2001, 183:490-499.

21. Harth G, Horwitz MA: Inhibition of Mycobacterium tuberculosis glutamine synthetase as a novel antibiotic strategy against tuberculosis: demonstration of efficacy in vivo. Infect Immun 2003, 71:456-464

22. Odell $L R$, Nilsson MT, Gising J, Lagerlund $O$, Muthas D, Nordqvist A, Karlen A, Larhed M: Functionalized 3-amino-imidazo[1,2-a]pyridines: a novel class of drug-like Mycobacterium tuberculosis glutamine synthetase inhibitors. Bioorg Med Chem Lett 2009, 19:4790-4793.

23. Harth G, Clemens DL, Horwitz MA: Glutamine synthetase of Mycobacterium tuberculosis: extracellular release and characterization of its enzymatic activity. Proc Natl Acad Sci USA 1994, 91:9342-9346.

24. Tullius MV, Harth G, Horwitz MA: High extracellular levels of Mycobacterium tuberculosis glutamine synthetase and superoxide dismutase in actively growing cultures are due to high expression and extracellular stability rather than to a protein-specific export mechanism. Infect Immun 2001, 69:6348-6363.

25. Harth G, Zamecnik PC, Tang JY, Tabatadze D, Horwitz MA: Treatment of Mycobacterium tuberculosis with antisense oligonucleotides to glutamine synthetase mRNA inhibits glutamine synthetase activity, formation of the poly-L-glutamate/glutamine cell wall structure, and bacterial replication. Proc Natl Acad Sci USA 2000, 97:418-423.

26. Amon J, Titgemeyer F, Burkovski A: A Genomic View on Nitrogen Metabolism and Nitrogen Control in Mycobacteria. J Mol Microbiol Biotechnol 2008. 
27. Harth G, Maslesa-Galic S, Tullius MV, Horwitz MA: All four Mycobacterium tuberculosis glnA genes encode glutamine synthetase activities but only $\mathrm{Gln} A 1$ is abundantly expressed and essential for bacterial homeostasis. Mol Microbiol 2005, 58:1157-1172.

28. Sarada KV, Rao NA, Venkitasubramanian TA: Isolation and characterisation of glutamate dehydrogenase from Mycobacterium smegmatis CDC 46. Biochim Biophys Acta 1980, 615:299-308.

29. O'Hare HM, Duran R, Cervenansky C, Bellinzoni M, Wehenkel AM, Pritsch O, Obal G, Baumgartner J, Vialaret J, Johnsson K, Alzari PM: Regulation of glutamate metabolism by protein kinases in mycobacteria. Mol Microbiol 2008.

30. Ahmad S, Bhatnagar RK, Venkitasubramanian TA: Changes in the enzyme activities involved in nitrogen assimilation in Mycobacterium smegmatis under various growth conditions. Ann Inst Pasteur Microbiol 1986, 137B:231-237.

31. Camardella L, Di FR, Antignani A, Ciardiello MA, di PG, Coleman JK, Buchan L, Guespin J, Russell NJ: The Antarctic Psychrobacter sp. TAD1 has two cold-active glutamate dehydrogenases with different cofactor specificities. Characterisation of the NAD+-dependent enzyme. Comp Biochem Physiol A Mol Integr Physiol 2002, 131:559-567.

32. Belanger AE, Hatfull GF: Exponential-phase glycogen recycling is essential for growth of Mycobacterium smegmatis. J Bacterio/ 1999, 181:6670-6678.

33. Villarino A, Duran R, Wehenkel A, Fernandez P, England P, Brodin P, Cole ST, Zimny-Ardnt U, Jungblut PR, Cervenansky C, Alzari PM: Proteomic identification of $\mathrm{M}$. tuberculosis protein kinase substrates: $\mathrm{PknB}$ recruits GarA, a FHA domain-containing protein, through activation loop-mediated interactions. J Mol Biol 2005, 350:953-963.

34. England P, Wehenkel A, Martins S, Hoos S, Andre-Leroux G, Villarino A Alzari PM: The FHA-containing protein GarA acts as a phosphorylationdependent molecular switch in mycobacterial signaling. FEBS Lett 2009, 583:301-307.

35. Niebisch A, Kabus A, Schultz C, Weil B, Bott M: Corynebacterial protein kinase $\mathrm{G}$ controls 2-oxoglutarate dehydrogenase activity via the phosphorylation status of the Odhl protein. J Biol Chem 2006, 281:12300-12307.

36. Müller T: Regulation of Glutamate Dehydrogenase in Corynebacterium glutamicum and its impact on nitrogen control. Universiteit zu Köln Mathematisch-Naturwissenschaftlichen Fakultät; 2005. Ref Type: Generic

37. Meers JL, Tempest DW, Brown CM: 'Glutamine(amide):2-oxoglutarate amino transferase oxido-reductase (NADP); an enzyme involved in the synthesis of glutamate by some bacteria. J Gen Microbiol 1970, 64:187-194.

38. Brenchley JE, Prival MJ, Magasanik B: Regulation of the synthesis of enzymes responsible for glutamate formation in Klebsiella aerogenes. J Biol Chem 1973, 248:6122-6128.

39. Patterson JA, Hespell RB: Glutamine synthetase activity in the ruminal bacterium Succinivibrio dextrinosolvens. Appl Environ Microbiol 1985, 50:1014-1020

40. Ikeda TP, Shauger AE, Kustu S: Salmonella typhimurium apparently perceives external nitrogen limitation as internal glutamine limitation. J Mol Biol 1996, 259:589-607.

41. Yan D, Ikeda TP, Shauger AE, Kustu S: Glutamate is required to maintain the steady-state potassium pool in Salmonella typhimurium. Proc Natl Acad Sci USA 1996, 93:6527-6531.

42. Kempf B, Bremer $E$ : Uptake and synthesis of compatible solutes as microbial stress responses to high-osmolality environments. Arch Microbiol 1998, 170:319-330.

43. ExPasy Proteomics Server CpMt [http://au.expasy.org/tools/ pi tool.html]. Ref Type: Generic

44. Hubbard JS, Stadtman ER: Regulation of glutamine synthetase. II. Patterns of feedback inhibition in microorganisms. J Bacterio/ 1967, 93:1045-1055

45. Carroll P, Pashley CA, Parish T: Functional analysis of GlnE, an essential adenylyl transferase in Mycobacterium tuberculosis. J Bacterio/ 2008, 190:4894-4902

46. Merrick MJ, Edwards RA: Nitrogen control in bacteria. Microbiol Rev 1995, 59:604-622

47. Harth G, Horwitz MA: Expression and efficient export of enzymatically active Mycobacterium tuberculosis glutamine synthetase in Mycobacterium smegmatis and evidence that the information for export is contained within the protein. J Biol Chem 1997, 272:22728-22735

48. Pfaffl MW, Horgan GW, Dempfle L: Relative expression software tool (REST) for group-wise comparison and statistical analysis of relative expression results in real-time PCR. Nucleic Acids Res 2002, 30:e36.

49. Amon J, Brau T, Grimrath A, Hanssler E, Hasselt K, Holler M, Jessberger N, Ott L, Szokol J, Titgemeyer F, Burkovski A: Nitrogen control in Mycobacterium smegmatis: nitrogen-dependent expression of ammonium transport and assimilation proteins depends on the OmpR-type regulator GInR. J Bacteriol 2008, 190:7108-7116.

50. Tiffert $Y$, Supra P, Wurm R, Wohlleben W, Wagner R, Reuther J: The Streptomyces coelicolor GlnR regulon: identification of new GlnR targets and evidence for a central role of $\mathrm{GlnR}$ in nitrogen metabolism in actinomycetes. Mol Microbiol 2008, 67:861-880.

51. Yuan C, Zins EJ, Clark AF, Huang AJ: Suppression of keratoepithelin and myocilin by small interfering RNAs (siRNA) in vitro. Mol Vis 2007, 13:2083-2095

52. Fink D, Weissschuh N, Reuther J, Wohlleben W, Engels A: Two transcriptional regulators $\mathrm{G} \ln R$ and $\mathrm{GlnRII}$ are involved in regulation of nitrogen metabolism in Streptomyces coelicolor A3(2). Mol Microbiol 2002, 46:331-347.

53. Jakoby M, Nolden L, Meier-Wagner J, Kramer R, Burkovski A: AmtR, a global repressor in the nitrogen regulation system of Corynebacterium glutamicum. Mol Microbiol 2000, 37:964-977.

54. Harper C, Hayward D, Wiid I, van Helden P: Regulation of nitrogen metabolism in Mycobacterium tuberculosis: a comparison with mechanisms in Corynebacterium glutamicum and Streptomyces coelicolor. IUBMB Life 2008, 60:643-650.

55. Fisher SH: Glutamate synthesis in Streptomyces coelicolor. J Bacteriol 1989, 171:2372-2377.

56. Loyola-Vargas VM, de Jimenez ES: Differential Role of Glutamate Dehydrogenase in Nitrogen Metabolism of Maize Tissues. Plant Physiol 1984, 76:536-540

57. Mitchison DA, Allen BW, Manickavasagar D: Selective Kirchner medium in the culture of specimens other than sputum for mycobacteria. $J$ Clin Pathol 1983, 36:1357-1361

58. Stadtman ER, Smyrniotis PZ, Davis JN, Wittenberger ME: Enzymic procedures for determining the average state of adenylylation of Escherichia coli glutamine synthetase. Anal Biochem 1979, 95:275-285.

59. Liu C, Mao K, Zhang M, Sun Z, Hong W, Li C, Peng B, Chang Z: The SH3-like domain switches its interaction partners to modulate the repression activity of mycobacterial iron-dependent transcription regulator in response to metal ion fluctuations. J Biol Chem 2008, 283:2439-2453.

60. Hu Y, Coates AR: Transcription of two sigma 70 homologue genes, sigA and sigB, in stationary-phase Mycobacterium tuberculosis. J Bacteriol 1999, 181:469-476.

doi: 10.1186/1471-2180-10-138

Cite this article as: Harper et al., Glutamate dehydrogenase and glutamine synthetase are regulated in response to nitrogen availability in Myocbacterium smegmatis BMC Microbiology 2010, 10:138

\section{Submit your next manuscript to BioMed Centra and take full advantage of:}

- Convenient online submission

- Thorough peer review

- No space constraints or color figure charges

- Immediate publication on acceptance

- Inclusion in PubMed, CAS, Scopus and Google Scholar

- Research which is freely available for redistribution 